\title{
Halal Tourism Based School Program Development in SMP 2 Selong East Lombok
}

\author{
Endang Susilawati \\ Graduate Student of Geography Education \\ Faculty of Social Science,Universitas Negeri Padang. \\ Email: endangsusilawati88@yahoo.co.id
}

\begin{abstract}
This study aims to obtain information and discuss about the development of school programs in SMP 2 Selong-based tourism in East Lombok. Research method used by researcher is research with qualitative approach. In this study as for the subject to be studied in this study are students and also educators at SMP 2 Selong Lombok Timur. Data analysis method used in this research is Analitycal Hierarchy Process (AHP). Analitycal Hierarchy Process is one of the methods used in solving problems that contain many criteria. Results and discussion of SMPN 2 Selong school program development based on halal tourism in East Lombok in the first development program on the implementation of Life Skills education that describes entrepreneurship and creative economy using AHP method. The first criterion of the development of handicraft programs from used materials that are marketed in tourist areas shows that this first criterion has the highest value compared with other criteria. The development of the second program is the development of education programs based on local and global excellence has five criteria where the development of Islamic-themed arts performance program implemented in the area of the highest criteria tourism object.
\end{abstract}

Keywords: Development of School Program, Halal-Based Tourism

\section{Introduction}

Lombok Island, which offers natural beauty that stretches from the eastern to the north end with endless tourist destinations. Pamper your eyes with endless beaches, bring coolness by playing under waterfalls, and pamper yourself with sunbathing or relaxing on the famous island, the gili matra (gili trawangan, gili meno, and gili water). Of course there is no end to discussing one by one natural wealth on this island of Lombok. Unexpected and unexpected, NTB became one of the icons of Halal tourism in Indonesia (Hafizah Awalia, 2017).

The meaning of kosher tours may vary for everyone. There is interpretation as the presentation of food from the halal materials or rules of tourism that follow the procedures in Islamic shari'ah (Salehudin and Luthfi, 2010 in Hafizah Awalia, 2017). Halal tourism is a new concept involving tourism management to respond to the needs of Muslim tourists. This involves the provision of services from the starting point to the destination including accommodation, transportation, restaurants, recreation, entertainment in accordance with Islamic principles, as well as unique facilities such as places to perform their daily prayers (Piyachat Puangniyom, et al., 2017). The definition of Halal Tourism is to prepare tourism programs and places that are designed to suit the needs of Muslim tourists. Tourism is a marketing effort to develop all products to target Muslim consumers despite the lack of religious motivation in entrepreneurs (Piyachat Puangniyom, et al., 2017).

Indonesia in 2015, especially the island of Lombok awarded as the best halal tourist destination in the world and in 2016 was awarded World's Best Halal Honeymoon Destination and the 1st World's Best Halal Tourism Destination from World Halal Tourism Award (Firdausi, et al., 2017). Halal tourism is a 
travel activity undertaken by Muslim tourists by visiting a certain place for recreational purposes within a certain time in accordance with Islamic Shari'a (Dogan, 2010 in Duman, 2011). Lombok which has a local advantage in the form of wealth of natural resources with a very interesting nature and wealth of human resources with hospitality owned Lombok society that most of the Muslims, so the main attraction to be developed local excellence Lombok globally. For that the development of school programs in the form of life skills education applications that describe entrepreneurship and creative economy and the development of education programs based on local and global advantages that need to be developed in SMPN 2 Selong Lombok Timur is a tourism-based activities halal. One form of appreciation in the development of human resources oriented to quality, competitive human resources are highly preferred in promoting national development in developing countries. To improve the quality of human resources, the participation of the government through the world of education can be developed through the school program so that learners have life skills that describe entrepreneurship and creative economy and the development of education programs based on local and global excellence.

Widoyoko (2010) states that the program is defined as a series of carefully planned activities and in its implementation takes place in a continuous process, and takes place within an organization involving many people. Sudjana (2004) argues that the program is an activity undertaken by individuals, groups, and organizations (institutions) that contain the components of the program. These components include objectives, objectives, content and types of activities, process activities, time, facilities, tools, costs, organization of operations and so forth. States that the program is defined as a series of carefully planned activities and in its implementation takes place in a continuous process, and takes place within an organization involving many people. Sudjana (2008) describes "the program development function will be used if the decision making determines that the program needs to be expanded or enhanced". The development of life skills programs that describe entrepreneurship and the creative economy and the development of local and global benefits-based education programs is essential to be developed at SMPN 2 Selong with halal tourism in East Lombok. Life skills are essentially psychosocial skills that include the personal, social, interpersonal, cognitive and affective components of an individual for a better life, one needs to have better decision-making and problem-solving skills (Kriti Vashishtha, 2015). The World Health Organization (1997) defines Life Skills, "as an ability for adaptive and positive behaviors that enable individuals to effectively address the demands and challenges of everyday life." Life Skills programs are extremely important at the school level. (Gagne, 1974, 1984; Stice, 1987 and Y. Sridevi, 2015).

Through the development of school programs with the application of life skills education that describes the entrepreneurship and creative economy as well as the development of education programs based on local and global excellence East Lombok which has tremendous potential especially related to halal tourism. By developing a school program that describes entrepreneurship and creative economy can bring learners to be able to develop their potential to be creative, entrepreneurial and later able to produce a creative economic products that can support education based on local and global advantages. Educational programs in schools will support the advancement of education in educational units, because the development of educational programs need to be considered to improve the quality of learners. Development of school programs include: The application of life skills education that describes entrepreneurship and creative economy as well as the development of educational programs based on local and global advantages. Currently, East Lombok education is in the process of considerable development and an increase of approximately $70 \%$ from last education because education here is the intervention or support that makes education in the process evolve. However, there are many schools that can not be reached by the government's attention, so the government should be able to develop further, with the support from various circles, both from the government and society and especially schools with the development of programs that are planned and focused on progress and development students and the world of education in East Lombok. 
Instructions to educate young students who can instill a sense of love and commitment to the local environment. In order for learners to know the local advantages of the area in which they live, understand the various aspects related to the local advantage. Thereby preserving the culture, traditions, and resources that become the regional superior, and able to compete nationally and globally (Wasino, 2008). A fun learning atmosphere (joyful learning) will be more meaningful if what he learned is useful for his life someday. During the study, learners get the provision of skills (life skill) is useful and valuable to face and maintain life (survive skills) in the future. Based on the above background the author conducted research on "Development of School Programs at SMPN 2 Selong based on halal tourism East Lombok".

\section{Method}

Research method used by researcher is research with qualitative approach. Qualitative research is a research procedure that produces descriptive data in the form of words written or spoken from people and behaviors can be observed (Meleong, 2010). According Sugiyono (2012) qualitative research is a research method used to examine the condition of natural objects, (as opposed to experiments) where researchers are as a key instrument. The reason the authors use qualitative methods because in conducting research is expected to run naturally as well as obtain the data objective and in-depth. The issues discussed to find out how the development of school programs in SMPN 2 Selong based on Halal tourism East Lombok.Location of research is in SMPN 2 Selong in East Lombok. In this study as for the subject to be studied in this study are students and also educators at SMP 2 Selong Lombok Timur. Data analysis method used in this research is Analitycal Hierarchy Process (AHP). Analitycal Hierarchy Process is one of the methods used in solving problems that contain many criteria. AHP works by giving priority to important alternatives following predetermined criteria. More precisely, AHP breaks down various hierarchical structure ranks based on objectives, criteria, sub-criteria, and options or alternatives to formulate the development of a halal-based school-based school program at SMPN 2 Selong, East Lombok district.

\section{Results and Discussion}

This research was conducted at SMPN 2 Selong Lombok Timur to see how the development of education program in SMP 2 Selong based on Halal tourism of East Lombok by using Analitycal Hierarchy Process (AHP) method. Using the Analitycal Hierarchy Process (AHP) methodology in the development of a halal-based school-based school program in East Lombok uses the first two supplers: the application of life skills education that describes entrepreneurship and creative economy. with several criteria: Developing handicrafts from used materials that can be marketed in tourist areas, performing arts of Muslim fashion from recycling on the beach, making Islamic gifts on skill subjects, making Islamic wall decorations, making halal traditional food. The second program of the implementation of education programs based on local wisdom danglobal, which consists of several criteria that is: make a school magazine that contains activities nuanced Islamic, make brending tours on display in the area of tourist attractions, Islamic themed arts performances held in the area of tourist attraction, in the tourist area, the big tablik held in the city park.

\section{Development of halal-tourism based school program at SMPN 2 Selong in East Lombok}

Application of Life Skills education that describes entrepreneurship and creative economy

Brolin (1989) explains that, "Life skills constitute a continuum of knowledge and aptitude that are necessary for a person to function and to avoid interruptions of employment experience." Thus life skills can be expressed as life skills. Life Skills education is not an independent subject, but it is fully integrated into the curriculum and extracurricular activities tailored to the mental, emotional, and spiritual conditions of learners. The Government of the Republic of Indonesia seeks to do so to improve the availability, 
affordability and quality of life skills of educational services for disadvantaged people through life skill education programs Life skills education in the perspective of national policy is interpreted from this aspect of economics means life skills education as an investment necessary to survival and acceleration of development. To develop a school program at SMPN 2 Selong based on halal tourism in East Lombok, it is necessary to apply life skills education which describes entrepreneurship and creative economy, among others:

Development of handicrafts from used materials that can be marketed in tourist areas.

Crafts are a unique expression of a particular culture or society through workmanship and local materials. The craft is part of a much larger home accessory market, which covers the challenges of barbecues. (Waqar Ahmad Khan, et al., .2013). Handicraft from used goods one business opportunity that uses little capital and reduce used goods that are not used, business opportunities this one much in demand by the community because in addition to utilizing used goods that are usually discarded but can make money, can even be a promising business opportunity. SMPN 2 Selong has utilized secondhand goods that are used as a skill or craft art that has high economic value through the development of school programs, but in SMPN 2 Selong has not utilized and maximize student artwork from used goods to be marketed in halal tourist area in East Lombok. It would be nice if the work already created by learners can be marketed in a tourist area so that the development of school programs with the application of life skills education that describes entrepreneurship and creative economy

The art performance of Muslim fashion from beach recycling material

To show tourists that education in East Lombok strongly supports halal tourism in East Lombok, it is necessary to develop a school program through SMPN 2 Selong. By performing senI Muslim fashion shows from recycling on the beach. This will illustrate that in East Lombok although on the beach however, all the people use Islamic dress that is suitable to the Lombok region which has the status of halal tourism in Indonesia. SMPN 2 Selong has developed students' creativity by making clothing from used materials such as from asbestos plastics, plastic beverage bottles, or plastic packing coffee with used clothes, making it the main attraction used during the parade in East Lombok district.

Making Islamic handicraft on skill subjects.

The effort to develop qualified human beings ready to face various challenges of life begins as early as possible through education. Educational activities are provided among others through a number of subjects intended to provide a meaningful and varied learning experience for learners. The emphasis on the type of skills chosen by the educational unit needs to consider the interests and talents of learners as well as the cultural environment, economic conditions and regional needs.

\section{Make Islamic wall Hanging.}

Various types of house wall decorations are found to beautify the house. One of them is again the latest popular wall decoration patterned islamic or decorate the walls with Islamic decoration. This wall decoration can be made by SMPN 2 Selong to support halal tourism in East Lombok.

\section{Producing halal traditional food}

In developing a halal-based tourism school program in East Lombok, traditional food greatly supports the advent of tourism in East Lombok. The need to hold a halal traditional food-making exhibition that SMPN 2 Selong can undertake in a tourist area to support a halal tourism-based school program in East Lombok.

The results of the discussion by using AHP that school development programs in SMPN 2 Selong based on Halal tourism East Lombok describes the first criterion of the development of handicraft programs 
from used materials that are marketed in tourist areas of 0.530 . This weight indicates that this first criterion has the highest score compared to other criteria of life skills education program which describes entrepreneurship and creative economy, while on the second criterion of the development of the performance of Muslim fashion show from beach recycling has the weight of 0.041 is a criterion with the lowest rating. The development of the third program makes Islamic syllables on skills subject has a value of 0.268 This is the second criterion that has a value below the highest value. While the fourth criterion of the program development makes the wall decoration nuanced Islamic get weight of 0.061 , while the program of the last criteria development of the program to make traditional food that kosher get the value of 0.099 which is the criterion with the value in the third rank.

\section{Provision of education based on local and global excellence}

Local excellence is anything that is characteristic of regionalism that includes aspects of economic, cultural, information and communication technology, ecology, and others. Another source says that local excellence is the result of the earth, art creations, traditions, cultures, services, services, natural resources, human resources or other advantages of a region (Dedidwitagama, 2007). The program of school program development of local excellence in SMPN 2 Selong in the form of natural resource potential based on halal tourism. so the need to develop some school programs in the form:

\section{Making the school magazine contains Islamic activities}

School magazines have 2 functions at once: (a) Islamic information rides, (b) information centers of Islamic activities, both internal and external schools. School magazines that can be made by SMPN 2 selong are school magazines containing school activities with Islamic nuances or other religious activities around the area of East Lombok based on halal tourism.

\section{Create a Islamic branding tour and on display at the tourist attraction}

To attract tourists, branding tours done by designing a logo and a unique tagline and highlight the hallmark of Halal tourism East Lombok. As branding of sharia tourism in eastern Lombok, the local government of Lombok Regency must work hard and cooperate with the world of education to involve learners to develop school programs by designing branding the nuances of Islamic. Promotion should be enhanced through any media, as well as road infrastructure.

\section{Islamic-themed art exhibition held in the area of tourist attraction}

To strengthen the position as World's Besat Halal Tourism, West Nusa Tenggara (NTB) held a festival event, as well as innovative halal tourism products are being intensively conducted NTB Provincial Government. After successfully held the event Qur'an Qabab (MTQ) National Level some time ago, the Office of Culture and Tourism of NTB Province also held BBLS event. Lombok presents Religious Art Performance, located at Islamic Center Mataram. The activities in the Performing Arts Performance is the appearance of Madad, Marawis, Rebana Burdah, Reban Lima, Zikir Zaman, Qasidah, and others. This is very supportive once Lombok as a tourist destination halal areas. So schools need to prepare the BBLS activities through the development of school programs, especially SMPN 2 Selong based on halal tourism in East Lombok.

\section{Implement mutual cooperation in the sights}

SMPN 2 Selong as a school located in the center of East Lombok district has implemented gotong royong at several places in the tourist area which become SMPN 2 Selong program needs to be developed. The development of SMPN 2 Selong school program based on halal tourism that needs to be developed again is to implement a big tablik in the city park, this can be done by SMPN 2 Selong by inviting walimurid to follow this activity so that the implementation of the school program, so that by developing this program can 
support Lombok East as a halal tourist destination area. Based on the discussion using Analitycal Hierarchy Process (AHP) method. that the development of school programs at SMPN 2 Selong based on halal tourism in the form of education based on local and global advantages has five criteria where the highest criterion is the development of Islamic-themed arts performance program held in the area of attraction with the weight of 0.580 , while the second level with the weight of 0.208 is on the development of the program in the form of branding tours that are nuanced and displayed on the Islamic tourist attraction. Making a school magazine containing Islamic nuances weighs 0.112 , this criterion earns a third score, and the development of a grand tabliq program held in the city park is the fourth criterion that gains weight of 0.064 . While the development program that obtained the lowest value is a criterion in the development of the implementation of gotong royong program in the tourist attractions.

Based on the results and discussion about the development of SMPN 2 Selong school programs based on halal tourism on the application of life skills education that describes entrepreneurship and creative economy. The first criterion for the development of handicraft program from used materials that are marketed in tourist area is 0,530 . This weight indicates that this first criterion has the highest score compared to other criteria of a Life Skills education program that describes entrepreneurship and the creative economy. Development of the second program in the form of local and global benefits based education has five criteria where the highest criterion is the development of Islamic-themed arts performance program implemented in the tourist object area with a value of 0.580 .

\section{Conclusion}

The development of a school program at SMPN 2 Selong based on halal tourism in East Lombok is the application of life skills education that describes entrepreneurship and creative economy. The development of handicraft program from used materials marketed in tourist area is very good to be developed. Development of the second program in the form of education based on local and global excellence is the development of Islamic-themed art exhibition program conducted in the area of tourist attraction.

\section{References}

Brolin, D.E, (1989). Life Centeredcareer aducation: trainer's manual. USA:BRILL

Chusorn, Pornpimona Ariratana, Wallaphab Chusorn, Prayuthc. (2013). Strategy challenges the local wisdom applications sustainability in schools, Procedia - Social and Behavioral Sciences 112 (2014 ) 626 634, Faculty of Education, Khon Kaen University, Khon Kaen, 40002, Thailand

Dwitama, D. (2007). Pendidikan Berbasis Keunggulan Lokal dan Global, (Online). Tersedia: http://dedidwitata.wordpress.com/22007/11/07/pendidikan-berbasis-keunggulan-lokal-global/.(3Okto ber 2017)

Duman, Teoman. (2011). Value of Islamic Tourism Offering Perspectives From the Turkish Experience. World Islamic Tourism Forum (WITF), Kuala Lumpur, Malaysia, 12-13 July 2011. International Burch University Sarajevo, Bosnia and Herzegovina.

Firdausi, Izza, Marantika, Stanijuanita, Firdaus, Zein Nidaulhaq, dan Sajidah, Rifqah. (2017). Lombok: Halal Tourism as a New Indonesia Tourism Strategy. 4th International Conference on Humanities, Social Sciences and Education (ICHSSE-17) March 13-14, 2017 Dubai (UAE).

Gagne R. (1974). Essentials of learning from instruction. Hinsdale, IL: Dryden.

Hafizah Awalia. (2017). Komodifikasi Pariwisata Halal NTB dalam Promosi Destinasi Wisata Islami di Indonesia, Jurnal Studi Komunikasi, Universitas Airlangga, Indonesia 
K.Vashishtha. (2015). Impact Of Life Skills On Leadership Development, Int. J. Soc. Sci. Manage. Vol-2, issue-3: 273-274, International Journal of Social Sciences and Management, Manipal University, Jaipur, India

Meleong, L.J. (2010). Metodologi Penelitian Kualitatif, Bandung, Remaja Rosda Karya

Piyachat Puangniyom, Nantawan Swangcheng, and Tosaporn Mahamud. (2017). Halal Tourism Strategy to Promote Sustainable Cultural Tourism in Thailand, 2017 CEBU International Conference on Studies in Arts, Social Sciences and Humanities (SASSH-17) Jan. 26-27, 2017, Cebu (Philippines)

Sudjana, Nana. (2004). Dasar-dasar Proses Belajar Mengajar. Bandung: Sinar Baru Algensido Offset.

Sugiyono. (2012). Metode Penelitian Kuantitatif Kualitatifdan R\&D, Bandung: Alfabeta

Tri Suminar, Titi Prihatin, and Muhammad Ibnan Syarif. (2016). Model of Learning Development on Program Life Skills Education for Rural Communities, International Journal of Information and Education Technology, Vol. 6, No. 6, June 2016

Waqar Ahmad Khan and Zeeshan Amir. (2013). Study of Handicraft Marketing Strategies of Artisans inUttar Pradesh and Its Implications, Research Journal of Management Sciences, Vol. 2(2), 23-26, February (2013), Dean, FMR, Integral University, Lucknow, U.P., INDIA

Widoyoko, Eko Putro S. (2010). Evaluasi Program Pembelajaran (Panduan Praktis bagi Pendidik dan Calon Pendidik), Yogyakarta: Pustaka Pelajar

Sridevi, Y. (2015). Life Skills Education In India, International Journal Of Multidisciplinary Advanced Research Trends ISSN : 2349-7408, Teaching Associate, IASE, AU, Andhra University. 